\title{
Truth or meaning: Ricoeur versus Frei on biblical narrative
}

\author{
Gary L. Comstock \\ Center of Theological Inquiry, Princeton, USA
}

\begin{abstract}
Truth or meaning: Ricoeur versus Frei on biblical narrative

Of the theologians and philosophers now writing on biblical narrative, Hans Frei and Paul Ricoeur are probably the most prominent. It is significant that their views converge on important issues. Both are uncomfortable with hermeneutic theories that convert the text into an abstract philosophical system, an ideal typological structure, or a mere occasion for existential decision. Frei and Ricoeur seem knit together in a common enterprise; they appear to be building a single narrative theology. I argue that the appearance of symmetry is an illusion. There is a fundamental conflict between the 'pure narrativism' of Frei and the 'impure narrativism' of Ricoeur. I give reasons for thinking that Ricoeur's is the stronger position.
\end{abstract}

God's work is mysteriously, abidingly mysteriously, coexistent with the contingency of events. The history of his providence is one that must be narrated. There is no scientific nule to describe it and eliminate the need for narration. Nor is there any historicist perspective or universal claim that can eliminate history's narrative form (Frei 1975: 163).

\footnotetext{
- This paper was read at the Iowa Postscript Society and the Narrative Interpretacion and Theology Group of the American Academy of Religion, December 1983.

Permission to print in HTS was granted by the University of Chicago Press, which holds the copyright to the article published in The Joumal of Religion Vol 66, No 21986.
} 
Of the theologians and philosophers now writing on biblical narrative, Hans Frei and Paul Ricoeur are probably the most prominent. It is significant that their views converge on important issues. For example, Ricoeur would agree with Frei's claim that narrative is indispensable for understanding God's work in history. Both would argue that scholars should attend to the Bible's literary forms before speculating about its theological significance. Both are uncomfortable with hermeneutic theories that convert the text into an abstract philosophical system, an ideal typological structure, or a mere occasion for existential decision. Each one is convinced that the meaning of realistic narrative is to be found in, not apart from, the story's own depiction of agents and circumstances. And each thinker puts great distance between his own work and the work of apologetics.

At first glance, the respective projects of Frei and Ricoeur seem knit together in a common enterprise; they appear to be building a single narrative theology. I will argue that this appearance of symmetry is an illusion. There is a fundamental conflict between the theologian and the philosopher, and I have tried to name it in my title. Is it enough to say that the biblical narratives are meaningful? Or are Christians also committed to saying that they are true? Frei thinks that the answer to the first question is yes, so he does not pursue the second. Ricoeur thinks the second demands an answer, and he tries to show how and why we should answer it affirmatively. 1

Frei believes that Christians must stop short of making claims about the truth of the biblical stories; to do otherwise tempts us to think that the story of Jesus can be judged and justified by the canons of modern scientific knowledge. 2 As far as Frei is concerned it should be the other way around. Eschewing, like Barth, the apologetic task of trying to explain the stories of God's providence to the nonbelieving public, he takes up the dogmatic task of finding appropriate norms to rule the use of these stories within the Christian community. For Frei, the scriptural stories have a singular meaning that is known to those within the bounds of Christian faith and practice. Insiders, however, are mistaken in trying to argue with outsiders about their truth.

Ricoeur agrees that the meanings of scriptural narratives are tied to their Christian audience. And he similarly believes that we ought to forgo apologetics. But he goes further than Frei on the matter of the stories' truth claim, holding that the way Christians use the stories is precisely to refer. He takes up the task that Frei rejects: The attempt to say what we might mean when we talk about the truth of the biblical narratives. This implicates him in a complex philosophical project, not the least problematic aspect of which is an attempt to rewrite modern theories of truth 
and reference. While his project, like Frei's, is far from complete, we now have sufficient statements from each thinker to hazard a comparison. I will argue that Ricoeur's is the more consistent position, and I will suggest that the philosopher's 'impure narrativism' is more faithful than the theologian's 'pure narrativism' to the testimony of the scriptural stories. 3

I

Students of biblical hermeneutics are deeply indebted to Hans Frei for his masterful reconstruction of the fate of the realistic reading of the Bible. Exhaustive in scope and painstakingly argued, The eclipse of biblical narrative is an achievement commanding wide attention; it is a work of classic stature, on the order of Erich Auerbach's (1953) Mimesis.

Frei traces the dissolution of the precritical scholarly consensus in which the literal meaning of the stories in Genesis, Exodus, and the Synoptic Gospels was taken to be none other than their true historical meaning. With the influence of deism, historical criticism of the Bible, and Hume's explication of the nature of historical claims, however, the veracity of the texts was called decidedly into question. The result? Biblical hermeneutics has been saddled ever since with the troublesome distinction between the meaning of the text (what it says) and its reference (what it is about). Frei carefully explains the various attempts to bridge this purported dichotomy between meaning and reference: The literalistic reading of fundamentalism (the text gives an accurate account of what really happened), the mythological interpretation of DF Strauss (the text points toward an ancient mythic consciousness and its set of sacred archetypes), and the rationalistic interpretation of Kant (the text reveals the universal process of turning from bondage to moral freedom) (see Frei 1974: 244, 256, 263).

Frei shows that not one of these attempts has been successful. Realistic narratives admit no separation of meaning and reference. The referent of this literary genre is a kind of internal one; what the text is about is found precisely in its literary form. In the Gospel of Mark, for example, lifelike characters confront one another in familiar surroundings. The scriptural author employs a simple rhetoric, neither artificial nor heroic in style, to depict believable, everyday events mixed with miraculous, unbelievable occurrences. The subject matter of Mark, then, is not found in historical events or philosophical arguments. It is found in the plot of the text and nowhere else. In Frei's words, what the text is about is identical with its verbal meaning. He proposes in Eclipse (admittedly in sketchy form) a new hermeneutic, what he calls a 'narrative interpretation' of the gospel story. 
According to this new method, we once again come to understand that story's meaning not as 'illustrated (as though it were an intellectually presubsisting or preconceived archetype or ideal essence) but constituted through the mutual, specific determination of agents, speech, social context, and circumstances that form the indispensable narrative web' (Frei 1974: 280).

More than any other critic, Frei has exposed the mistake of separating the gospel's 'propositional content' from its 'literary form'. Theologians in the last few centuries have almost universally misunderstood stories such as the first three chapters of Genesis, Abraham's sacrifice of Isaac, and Mark, thinking of them as enjoyable, aesthetic embellishments of some more basic, underlying message. But realistic narratives are not that. At once ordinary and extraordinary, they mingle noble and serious themes with casual, everyday occurrences. As a result, we are wrong to think of them as histories that refer to actions and events behind the text. We are also wrong to take them as myths referring to timeless archetypes (or universal principles) above it. Like the American New Critics who vigorously opposed 'the heresy of paraphrase' (see Yu 1978: 198-203), Frei (1974: 281) teaches us to reject any interpretation that finds the meaning of these stories in some 'mysterious realm of being and meaning', or in a 'separable subject matter', or in any 'combination of such behind-the-scenes projections, the meaning of these narratives is autonomous; they refer only to themselves. Mark means what it says and not another thing. As Frei $(1974: 27,33)$ puts it, scripture 'simultaneously depicts and renders the reality (if any) of what it talks about'; its subject matter is 'constituted by or identical with its narrative'.

I will refer to Frei's hermeneutic theology as 'pure narrativism'. It has many features to commend it. It insists that stories are primary in the order of human knowing and acting. It denies that history-like stories are reducible to historical, mythical, or philosophical propositions. Such narratives cannot be translated into any other discursive form. Pure narrativism restores to Christian theology the centrality and authority of the gospel's form, reminding us that the original witnesses to Jesus' life chose to tell stories about him and highlighting the fact that our religious convictions are best displayed in stories. ${ }^{4}$

These beliefs unite the pure and not-so-pure story theologians. The main difference between them concerns the question of defending these claims. If someone were to ask us to justify them, what would we say? If someone were to ask how we know that the biblical narratives are true, how would we respond? Frei and Ricoeur agree on many things, but they do not agree on the answer to this question. They do not even agree that it is important. Both hold that the New Testament narrative of Jesus is essential for Christian faith and practice, but only Ricoeur 
believes that we can or should try to justify this belief as true. Frei does think the Christian story a true one, but only Ricoeur has gone on to try to spell out just what such a claim might entail. This may well be the major difference between pure and impure narrativists; only the latter believe it important to develop a theoretical justification of narrative hermeneutics. 5 For whatever reason, the former see little use for that particular philosophical project. 6

I believe that the impurist's response is the correct one. I will argue my case by trying to demonstrate that - despite its distaste for theories - pure narrativism rests on certain foundational principles. And they are principles ill suited to the narrative reading of the gospel.

Pure narrativists hold, correctly I think, that realistic stories are immediately intelligible to us. Intimately bound up with human self-understanding stories may well be the first literary structure that young children learn to follow. Those of us graced with the presence of the elderly know that stories are the favorite pastime of the very old. And when we think about the fundamental issues of human existence the 'big' questions of life and death, the growth and decay of character and culture we naturally do so in terms of stories (cf MacIntyre's 1981 position). Some purists have argued not only that human life and community are story shaped but also that our very world has a narrative structure. Frei has not rested his case on any of these claims, but they do support his view; we are so adept at understanding stories that we have no need of any sophisticated theory to help us understand them.

As I have said, Frei does not appear interested in developing the philosophical foundations of 'narrative hermeneutics'. He is more interested in persuasive and sensitive readings of specific Christian texts. In Identity, Frei (1975) criticizes those 'high-level' hermeneutic theories that bury the subject matter of, say, Mark underneath 'ambitious' and 'all-encompassing' theories of 'understanding' or 'being'. He would appear to have the 'new hermeneutic' of Fuchs and Ebeling in mind, but one cannot help but wonder whether he would now include Ricoeur as one whose theory endangers the specific message of the gospel. 7 "When this "new hermeneutic" view, with its claim to omnicompetence in interpretation, is applied to realistic narrative, not only is the subject matter turned into something other than the story and what it depicts, but even what is supposed to be the true subject matter is nothing except in and by the relation and family resemblance between it and the interpreter' (Frei 1975: xvii).

Frei objects to the practitioners of the existentialist hermeneutic (be they Americans, Germans, Freudians, or structuralists) for allowing their 'general theory' to 'dictate to' their exegetical practice. He makes no bones about his displeasure with these methods; they are 'useless', operating at an 'ethereal level', inadequate as 
guides for interpreting the actual stories of the New Testament.

Frei has no use for such all-encompassing hermeneutic foundations. But this is not to say that he is an antifoundationalist. $8 \mathrm{He}$ does not make a great deal of them, but he is at least aware of his own general interpretive principles. I find at least two tenets grounding his proposal for 'narrative interpretation'. These might be formulated in terms of a general literary principle and a general philosophical principle. One of Frei's literary foundations is that the meaning of a realistic narrative is autonomous. Meaning is tied neither to its author's nor to its reader's beliefs, intentions, or practices. In the quote above, Frei scores those who closely tie the subject matter of the biblical text to the response of an interpreter. One of Frei's philosophical foundations is related. The narratives of the Bible are self preferential, not referring to anything other than themselves. Earlier, I indicated the extent to which Frei distances realistic narrative from history, myth and philosophy.

If I am right to think that these are Frei's conceptual foundations, then I can understand his reason for backing away from discussions of the stories' truth. In the modern period, discussions of truth focus on propositions and how propositions correspond to external reality. Such arguments rarely consider linguistic units longer than the sentence. Textual forms - such as narratives - are never considered. Given this philosophical prejudice, stories cannot be considered as either true or false. Only individual statements in the story can be granted that status.

Unfortunately, Frei's view does not challenge this prejudice. Pure narrativists are content to except narratives from the rigorous debate about truth conditions. Stories, they tell us, do not make assertions about the world. Narratives are not interested in 'corresponding' to some reality outside them. Thus, we have no need to ask about their 'truth'.

I do not think we should be content with this account. Frei's exegetical practice is masterful, and his actual reading of the gospel is one that, happily, is receiving more and more attention. But I believe that this reading receives no support from his (stated or implied) theoretical foundations. Indeed, I am convinced that both of his theoretical principles are mistaken and that the particular confessional theology associated with them does not do justice to the intentions of those who hear and tell the New Testament story as their own.

Frei's first book chronicles the history of errors of the last several centuries of synoptic criticism. It argues persuasively that these scholars have almost universally misinterpreted the story, primarily because they have misconstrued its genre. On Frei's reading, the gospel is a carefully constructed and unique literary work. Its peculiar aim is to identify the singular man Jesus of Nazareth while also rendering 
him present to the reader. How can these two goals possibly be achieved? The answer is found only in getting clear about the precise identity of the main character. Jesus is not only a carpenter's son, born in Bethlehem, baptized by John, and crucified in Jerusalem. He is also the Savior, the Redeemer, the Son of God resurrected from the dead. According to Frei, the text intends to show the reader that the 'fictional Jesus' (my own phrase) 'is what he appeared to be - the Savior Jesus from Nazareth, who underwent "all these things" and who is truly manifest as Jesus, the risen Christ' (Frei 1975: 138).

This is at once an original and traditional interpretation; it retrieves in a modern idiom the ancient literal and figural readings on which Christian identity is based. It is a reading on which pure and impure narrativists might agree. My interest here is not in the soundness of the exegesis but in the fit between this reading and Frei's hermeneutic theory. Let us remind ourselves of its bases. As a literary foundation, Frei holds that texts and readers are independent. As a philosophical foundation, he claims that stories are not reducible to propositional claims. Can we harmonize these tenets with his interpretation of the gospel? I do not think so. It seems that at the level of practical exegesis, Frei finds a specific reader response in 'the text itself' as well as a specific truth claim apart from which the story's meaning is unintelligible.

Let me explain. Consider first Frei's principle of autonomy.

According to Frei's theoretical suggestion, the meaning of a realistic story is separable from the receptive intentions of its audience. But in practice his reading seems to demand what we might call a 'correctly interpreting reader', one who is actually having the experience outlined by the text. No reader will get the meaning of the gospel narrative unless he simultaneously knows the presence of Jesus Christ. If that particular experience is lacking, if the reader fails to identify and encounter the fictional Jesus, then the narrative's meaning is not present at all. Only under those conditions in which we have a 'proper reader response' (my phrase) will the meaning of this text occur. For only then can we affirm, with Frei, that Jesus' textual identity and his existential presence are given together.

Now, a question arises as to whether a non-Christian reader can know who the fictional Jesus is without ever encountering the living Christ. Frei's answer is ambiguous. Christians, he says, 'are forced to consent to the factuality of what we represent to ourselves imaginatively. We must affirm that to think of [Jesus] is to have him actually present, (Frei 1975: 15). But what about non-Christians? Can the unbeliever know who the protagonist of this story is? Apparently not, for whenever anyone really knows who Jesus is, there Jesus is present as well. Not to have him present or not to be experiencing his presence would, on Frei's view, be the same 
thing as not to be thinking of him at all. But, of course, unbelievers just are those for whom Jesus is not present or who, at least, do not experience that presence. So it seems that unbelievers cannot understand the story, not being able to understand who the major character is.

Here are the two passages in which Frei most clearly expresses his position: 'For the believer to know who Jesus Christ is, to affirm his presence, and to adore him are one and the same thing .... Just as Christ's presence and identity cannot be conceived apart, factual affirmation of him and commitment to him cannot be conceived apart either'. 'For whomever [the story] becomes the truth it does so ... by hammering out a shape of life patterned after its own shape ... the shape of the story being mirrored in the shape of our life is the condition of its being meaningful for us' (Frei 1975: 156, 170-171). In these passages the ambiguity remains as to whether Frei thinks Jesus' identity is given only to Christian readers of the text. In the first passage he says Jesus' presence and identity go together 'for the believer'. In the second, he says mirroring the shape of the story in our own lives is the condition of its being meaningful for us. The context of the second quotation implies that Frei is once again referring to Christians, but one could read it as referring to any reader. If 'living out its shape' is a necessary condition of the story's being meaningful for Christians, must not it also be a condition its being meaningful for anyone else? In support of this interpretation is Frei's own definition of realistic narrative. Recall that the meaning of any story of this sort is intelligible to all, it is a genre that 'renders its sense to the reader, no matter how he disposes himself toward the story on a personal level' (Frei 1975: xv).

The ambiguity of Frei's position on this subject is not worth belaboring. What is clear is that Frei insists on the coincidence of Jesus' identity in the text with the experience of the risen Christ by the reader. The story's meaning is found, as it were, 'between' the text and the audience. ${ }^{9}$ As the reader sympathetically follows the progressive unfolding of Jesus' identity in the narrative she must simultaneously be 'affirming' and 'adoring' him in the present. If not, the reader has missed the story's meaning because she has not correctly identified its major character. Frei's actual reading shows that in the case of at least this one realistic narrative, meaning is unintelligible apart from reader response. That is, we cannot say what the meaning of the story is without referring to what is going on with the reader. But this, of course, is just what the doctrine of autonomy was meant to deny.

Is there a way to save the idea of autonomy? That depends on how strictly we wish to take it. One way Frei could retrieve it would be to say the following: this story's meaning really is autonomous, but it is only available to a certain class of readers. This interpretation would harmonize Frei's theory with his practice; the 
gospel's meaning really would be independent of its readers, but only a select few would have access to it. While this would harmonize Frei's theoretical commitment with his exegetical practice, it is clear that he does not want his theory understood in this way. He has recently cited with approval Calvin's comment that while 'our hearts and minds may need illumination, the text does not. It is plain for all to read' (Frei 1982: 22). If his interpretation of the gospel is so at odds with his foundational literary principle, why does he advert to it in the first place? The answer may lie in its theological implications.

On the interpretation I have just offered, Frei's position reads as a kind of fideism; in order to understand the gospel you must first believe in Christ. But Frei seems to know the intractable problems that accompany this position. By insisting on the doctrine of autonomy, he has a way to elude the charge of theological sectarianism. By claiming that the gospel is a realistic narrative, and by defining that genre as one whose meaning is accessible to all, Frei has a neat way to escape from the fideistic corner.

If I am right about the inappropriateness of his autonomy doctrine, however, his escape seems much less believable. The logic of his view entails that he get tremendous theological mileage out of a literary vehicle he does not really own.

There is another way for him to salvage the autonomy principle. That would be to say that the meaning of every realistic narrative is autonomous but, in the specific case of the New Testament writings, the activities of the reader are to be construed as part of the text itself. In this way, the continuing spiritual presence of Jesus in the church (that is, in the group of correctly interpreting readers) could be construed as an irreducible part of Jesus' identity in the story.

This second interpretation again seems to preserve the doctrine of autonomous meaning. Imaginatively enlarge the boundaries of what you consider as 'the text itself, include all Christian readers' experiences of Christ's presence in it, and we can still hold on to the New Critics' principle.

This seems like a viable option for Frei until we stop to think about what has happened to the original doctrine. Its meaning has now been stretched so far that it is impossible to give it any clear sense. The text's meaning on this second interpretation is no longer independent of its readers' activities at all. The identity of the main character in the book is tied to a vast range of persons, rituals, and institutions not even alluded to by the text. These are surely 'extratextual' matters, not at all within the margins of any autonomous 'text itself. I conclude that autonomy is a hermeneutic principle that conflicts with Frei's own narrative reading of the gospel. We will want to find a better explanation of the text-reader relation. 
Now think about Frei's philosophical principle that states that narrative is selfpreferential. How are stories connected with the world, with nonnarrative modes of discourse, with propositional truth claims? On this matter, too, Frei, in principle, allows little relationship if any. The gospel does not refer to anything external to or outside itself. Narratively referring to its own world, the meaning of the story is neither a set of assertions nor a sequence of temporally ordered propositions. Realistic narratives do not invite readers to assess the truth of each of their sentences (as if they were histories), nor do they invite an appraisal of their logical coherence (as if they were philosophical arguments). Rather, these narratives are linguistic units in their own right, depicting or rendering their own subject matter. We have already seen what this subject matter is in the case of the New Testament. It is a unique meaning, one that claims the entire being of the reader. To understand the text properly is to consent to enter the language game of Christian belief and practice.

While Frei is theoretically committed to the self-referentiality of the story, his actual reading of the gospel strains his theory. His practical exegesis demands that we think of the story of Jesus as pointing, in part, to a complex range of human activity: namely, piety. The reference of the story is at least partially to the 'form of life' in which Christ is experienced as present. This view holds out great promise for introducing sacramental theology into narrativist discussions. But it does not sit well with the principle of narrative self-reference.

Why is Frei attracted to this foundation? We can only speculate, but again there seems to be a theological explanation.

Frei gets two things from his principle. The first is an argument against apologetics. It will not make any sense for Christians to try to engage in rational conversation about whether Jesus was actually born to Mary, baptized by John, or raised by God if this story can only be understood by Christians. The conversation would only make sense to those who know whom it is we are talking about. And, by virtue of the nature of Jesus Christ, only believers know who that is. But, since rational conversations by definition are open to all reasonable persons, we have no reason to think that we can or ought to participate in one in which Jesus is the subject. In such instances, our response ought not to be conversing or arguing but proclaiming.

Second, because our beliefs are not open to the sort of public scrutiny that modern philosophy has come to demand for truth claims, members of the Christian religion are entitled simply to claim that when we talk about Jesus' identity we are not making rational, 'true' claims. The payoff, of course, is that we cannot be charged either with saying things that are false. 
This kind of confessional view has much to recommend it. Here, choosing the Christian life is choosing to picture the world in a certain way; Wittgenstein (1966; 1969) refers to this phenomenon as 'seeing-as'. The believer sees the world as a certain configuration; perhaps as a world of grace, guilt, and salvation. The unbeliever sees the world as a different configuration; perhaps as a world of cause, effect, and fate. The question of which view is 'true' does not arise for Wittgenstein because the believer and the unbeliever are simply 'using different pictures'. 10

Frei's narrativism is reminiscent of Wittgenstein. Any question about the 'truth' of biblical narrative is an unfortunate category mistake. Before getting embroiled in modern theories of truth, one ought to stop and realize that the terms have already been botched. The scriptural narratives are like a picture of the world, a way of 'seeing-as'. Thus, the Christian picture cannot be more 'true' than any another; such pictures do not compete. They just do different things, have different motivations, uses, and purposes. The one who sees the picture of the rabbit-duck 'as' a rabbit is not seeing anything more truly than the one who sees it 'as' a duck. The one who sees the world as graced is not seeing anything more truly than the one who sees it as chance. They are simply seeing different things and, considering what they are seeing, the language of truth does not apply.

Frei's theoretical commitment to self-referentiality affords him a second out; he now can excuse himself from those arguments that try to compare the beliefs and practices of Christians and non-Christians. Since there can be no cognitive issue between these two groups, we need not attempt to match one up against the other. The respective ways of 'seeing-as' are incommensurable. Each is playing a different game. Basketball and golf are played by different rules. As a golfer's score will mean nothing in the National Basketball Association, so the results of Christian theology cannot be translated into the arena of secular life. Thus, it is another mistake to try to show in the public realm that Christian views are true.

This theological position is also attractive. It reminds us, for example, that the meaning of the Scriptures is inseparable from the form of life of Christian piety. It allows us to move beyond the seemingly interminable discussions of 'whether God exists' to get on with systematic and dogmatic theology proper. And it reemphasizes that religions are not merely intellectual systems but are also concrete forms of human practice: Personal and institutional patterns of behavior. There is, however, an important reason for rejecting this perspectivism. It does not seem to do justice to the intentions of just those believers who tell and retell the scriptural stories as their own. (Nor, incidentally, does it appear accurately to reflect the testimony of the first tellers of tales about Jesus. But since I am not concerned here with authorial intention, I will not try to argue for this claim.) 
Consider a crucial episode in the gospel narrative, one which is rehearsed every Easter morning. At that time, many Christians appropriate the resurrection story for themselves and their community, affirming to one another, 'He is risen'. If Frei's Wittgensteinian view is correct, this utterance is guaranteed a meaning within the believing community while it is denied the possibility of being intelligible outside it. That is, if any unbelievers are standing nearby, they are not able to understand the claim, simply because they do not know the presence of Christ. (Remember: they do not know how to identify the subject of the proclamation.) If they do not know who 'he' is, then they cannot follow the claim. But if they cannot follow the claim, they surely cannot contest it. Unable to contest $i t$, they cannot object to it. If the pure narrativists are right, it turns out that it is literally impossible for Christians and non-Christians to disagree about the resurrection.

I doubt that this is what most Christians understand themselves to mean when they confess the Easter faith. Many Christians - irrespective of whether they are naive and 'precritical' or liberal and 'post-critical' - perceive some tension (if not contradiction) between their beliefs and the results of modern science. Will not these Christians feel more affinity with the atheist who disputes their claim than with the Wittgensteinian theologian who tells them it is immune from criticism? Will not many who affirm Jesus' resurrection say that it is the atheist, and not the theologian, who is really playing their game by their rules?

The idea that biblical narrative is self-referential offers the pure narrativist a reason for being excused from any 'public conversation' about the narrative's truth. But I think it fails as an explanation of the self-understanding of just those believers who most sincerely understand the gospel as history-like narrative. And it seems dubious to me that the biblical writers themselves would have understood their stories in this way.

Like the principle of autonomy, self-referentiality will not do as a theoretical foundation for narrative theology. Neither will the associated theological positions of fideism or Christianity as an autonomous language game. As I have said, I do not want to give up Frei's suggestions for reading the New Testament story. I want to find a more consistent set of hermeneutical principles for talking about that reading.

II

I am now in a position to state what I take to be the central aporia of pure narrativism. On the one hand, pure narrativists believe that stories are foundational and primary in the order of human knowing and acting. On the other hand, they do 
not want others to treat this conviction as if it were just one more way of looking at things, 'just another story', as it were. Purists would like others to see the truth of the Jesus story. But in order for them to move toward this goal, at least one of the things they will have to begin to do is to reason with us. Inevitably, this means entering the game of rational argumentation: making a claim, explaining its grounds and warrants, and allowing it to be critically scrutinized. When it comes to this point, however, the purist holds that Christian identity is on the line; either one sticks to the ultimate authority of 'the story itself and lets the chips fall where they may, or one abandons the story - and the narrativist position - altogether.

To my mind, this response begs the question of whether narrative theology really intends to say something about the world. I do not think that we can have it both ways; either we are making truth claims or we are not. If we are not, then we must be content to have others say about us: 'Oh, the Jesus narrative again; that's just their story about things'. If we are - if we think that in an important sense this story is a true story about things - then we must accept responsibility for showing not only how one ought to understand the claim, but why it should be affirmed.

Some recent articles by Paul Ricoeur suggest one way we might do this.

In the past, Ricoeur has emphasized the 'semantic autonomy' of the meaning of sentences. I will argue here that his recent turn to the 'text', however, has led him increasingly in the direction of an aesthetics of reception (cf Ricoeur's 1980: 272 appreciative remarks about Hans-Robert Jauss 1977). He now seems willing to commit himself theoretically both to the presence of readers in texts and to the presence of truth claims in stories. Ricoeur would certainly agree with Frei that such truth claims present special problems for analysis; God is not an object about whom verifiable of falsifiable propositions can be asserted. But for the philosopher, religious utterances do make publicly intelligible claims about what is the case, and they do refer in their own remarkable way. He goes to work on specifying the sense in which religious discourse may be said to be true.

In order to show how an impure narrativism can solve the purist's theoretical difficulties, I begin with Ricoeur's revisionary contributions to the modern philosophical discussion of truth, moving on to consider his view of religious language. Only at the end of this sequence of projects do I take up his position on the specifically biblical narratives of Jesus. 11

In order to begin building a justification for the truth of biblical narrative, we must first try to answer this question: To what sort of truth do biblical narratives lay claim? Ricoeur understands these stories as a species of religious language. Religious language in turn is a form of poetic discourse. In it the human imagination is at work, creating new forms of response to God's actions upon us. On 
Ricoeur's view, the truth claims of religious texts are more like those of the poet than of the historian or the scientist.

In the process of trying to explain how artistic and religious languages refer, Ricoeur finds it necessary to describe a level of discourse that has been ignored by modern philosophy and linguistics. This is the level of the text, and Ricoeur insists that we grant it a place alongside the more familiar units of word and sentence (or name and proposition).

Ricoeur's theory of textual referentiality goes something like this. The sense of a word is a concept; the reference of a word is an object in the world. The sense of a sentence is a proposition that predicates something of a linguistic object. The reference of a sentence is its truth value, whether the proposition accurately maps objects onto the extra-linguistic state of affairs (Ricoeur 1977a: 75, 218). These views are all generally consistent with work in the Fregean tradition. But, argues Ricoeur, they do not take us far enough. Analyses of names and propositions must be complemented by analyses of the texts in which these units are found.

The proposition has a different way of referring than does the word. The text has yet another way of referring than either of these units. Texts have a sense; the sense of a narrative text is its plot. 12 But texts also have a reference; the reference of a narrative text is the possible world it creates (Ricoeur 1977: 218). Even in the case of the most self-referential of texts, we can conceptually distinguish meaning and reference. Ricoeur insists that we must not separate the two; the intelligibility of each term depends on the presence of its partner. But neither are they strictly identical.

The figure of the ellipse might serve as an appropriate analogy here; the linguistic genre we call realistic narrative can be construed as a geometrical figure whose shape is determined by two inseparable but distinct poles. On the one hand, neither pole (e g, meaning) will make sense without its partner (reference). If one pole is displaced or given greater weight, the figure will be distorted; we will end up with an ovoid rather than an elliptical shape. On the other hand, the two loci cannot be conflated. If the two poles are collapsed into one, the figure will shrink into a circle. In either case, we have something other than realistic narrative. As Ricoeur has said of another matter, this dialectical relationship is a polarity or tension which must not disappear into a simple identity, nor harden into a sterile antinomy, or still less an unmediated dichotomy' (Ricoeur 1978: 13-14). Pure narrativists seem to succumb to the first temptation, allowing narrative reference to disappear into a simple identity with narrative meaning.

Making use of Ricoeur's hermeneutic theory, we can now substitute a principle of dialectical meaning for Frei's autonomy principle. This will allow us to 
distinguish conceptually between 'what the story says' and 'what it is about' while still being able to insist that each is unintelligible without the other. In order to see what this view entails, we must consider more carefully Ricoeur's conception of narrative reference.

The philosopher would agree with Frei that the meaning of a history-like story is its plot, the ongoing interaction of character and circumstance directed toward an end. But, for Ricoeur, this plot is always interpreted by some historical audience; one should not think 'plot' without thinking 'the plot according to whom?' When we do think in this way, we see the plot opening on to an entire world, a 'possible world'. And the specificity of that world will be determined not simply by textual evidence, but by how that textual evidence is construed by a specific historical audience. For Ricoeur, like Frei, the plot (or 'meaning') is found 'in' the text's rendering of agents and events. But Ricoeur adds that the world ('referent') of the text always arises in the fusion of horizons between text and reader; it is a world possible for someone. In the case of written texts like the Gospels, the someone is a reader. So we should not say that the referent of the story is confined to the text itself. On Ricoeur's Gadamerian view, a text is a structured interpretation of something by someone for someone else: A specific configuration whose meaning constantly depends upon the enacting, co-productive activity of an interpreter.

Like Frei, Ricoeur denies that realistic narratives refer ostensively to real objects, agents, or events behind the text. Nor does he think that they refer to archetypes, ideas or forms 'above' it. These fictional (Frei: history-like) stories suspend the everyday 'first-order' referentiality of language. But in doing so, they create a new, 'second-order' mode of reference: a possible world. (Remember that this is not unprecedented in the linguistic scheme of things. Each new level of discourse adds a new order of reference to the previous level. A name can denominate, but it takes a sentence both to denominate and predicate. In the same way, it takes a text to denominate, predicate, and create a possible world.)

Ricoeur's ground-breaking discovery of the linguistic 'textual' unit enables him to enter the philosophical discussion of truth with a bold message: The three levels of discourse are always intertwined. In one way this is obvious; sentences are always made up of words, and texts of sentences. But, says Ricotur, it is also true that words always imply (hidden) sentences, and sentences always imply (hidden) texts. I cannot presume to try to prove this claim here, but I will try to illustrate what it might mean.

Consider the name Jesus. All by itself it has a wide variety - perhaps an infinite number - of potential meanings. So we cannot begin to talk about any one of them until we begin to pick out one or more of the propositions in which it is used. We 
begin, for example, by moving from the name Jesus to the sentence 'The Jesus I am thinking of is a Latino who wears a black leather jacket'. But even this sentence has a vast plurality of possible references. In order to indicate which reference I intend, I must identify that story that gathers together the exact set of sentences I have in mind. When I do this, I move from the level of propositions to the level of texts: 'The Jesus I am thinking of is a Latino who wears a black leather jacket. This week he refused to cut a deal with Frankie on "Hill Street Blues". This caused Joyce to do $x$, and the mayor to do $y$, which led to ... and then to ... until finally ....' and so on.

We can conceptually distinguish and individually investigate names, propositions, and narrative texts. But on Ricoeur's theory we can never rigidly separate these levels. They are mutually constitutive, imaginable perhaps as a rounded figure with, now, three essential foci. Each word, when used, implies a specific set of propositions. Each proposition, when used, implies a specific set of stories.

If Ricoeur is right, all those concerned with questions of truth and reference will have to expand their territory to cover the peculiar domain of textuality. The tools of semantics and symbolic logic will not suffice for work in this area. We must begin to take account of such things as plot and character, theme and suspense, mood and setting. 13 This may well be one of Ricoeur's most important contributions to the contemporary philosophical conversation. What is important for our purposes, however, is that Ricoeur's discovery of the level of the narrative text provides a way to locate our claims about the truth of biblical narrative. Religious narratives intend to uncover the largest 'text' of human temporality. They are offered as ultimate stories within which all of our speaking and doing is revealed in its final significance.

Ricoeur is not willing to say that the biblical narratives are true and then withdraw from the discussion. Nor does he adopt a strategy in which talk about religious truth would remain confined to the 'theology' corner of the academy. For Ricoeur, the truth of biblical narrative does not inhabit its own autonomous language game; these stories present publicly intelligible - if extremely complex and ambitious - claims about what is the case. ${ }^{14}$ On my reading, Ricoeur is decidedly not a literary autonomist or theological fideist.

For an impure narrativist, religious stories can and do make truth claims. What are these claims about? They are about the nature - at once mundane and extraordinary - of living in time. Narrative, in which plot plays such a crucial role, is primarily concerned with the temporal makeup of our world. The truth claims of the biblical stories are claims about the innovative capacities and persistent characteristics of our species. Those stories purport to tell us about the outer borders and central heartland - the ultimate limits and daily rhythms - of 
specifically human existence.

To Frei this may begin to sound like a sophisticated version of apologetics, a new 'new hermeneutics' in which the interpretation of the Bible 'becomes practically equivalent to general philosophical inquiry; and the language-to-be-interpreted becomes shorthand for a whole philosophical or theological anthropology' (Frei 1975: xvi). Is impure narrativism just the most recent attempt to turn Christianity into a universalist religion of being or language or, now, biblical narrative? In order to answer this last question, we must remind ourselves of the trajectory I have followed in presenting Ricoeur's position. I have introduced Ricoeur's attempt to reorient the contemporary discussion of truth toward the level of the text. And I have considered his general views about the truth of artistic and religious narrative. But I have not yet turned to his specific views about the biblical narratives of Jesus.

Since Ricoeur's literary and philosophical principles (dialectical meaning and possible worlds reference) differ so markedly from Frei's, we might expect him to read the Gospels differently as well. Ricoeur's interpretation is at once more universalistic and more pragmatic, concentrating on the kingdom of God where Frei concentrates on Jesus' identity. If Frei understands the stories as passion narratives with long introductions, Ricoeur understands them as extended parables about the kingdom. For Ricoeur, the texts are the end result of a process in which the oral kerygma was transferred to written form. In them, he sees Jesus the teller of parables becoming Jesus the parable. He commends John Dominic Crossan's way of putting this: 'Jesus proclaimed God in parables, but the primitive church in the redaction of these stories proclaimed Jesus as the Parable of God' (cf Ricoeur 1981: $100)$.

For Ricoeur, the 'proposition' of the text is not so much 'the textual Jesus is the risen Christ' as it is 'Jesus' life reveals the mystery of the kingdom of God'. This mysterious kingdom is not an imaginary or neutral world; as it is interpreted by specific individuals and communities, it becomes truly a possible world. It bears down upon us, making its presence powerfully felt. We often encounter its disruptive power in innovative forms of language - poetic language, especially the parable form so favored by Jesus. Through learning to hear the truth claim of this odd linguistic form, we may at last learn part of its message; everything, finally, is not in our control. We are not the masters of the universe.

For Ricoeur, this mysterious power is potentially present wherever language is used creatively. It can irrupt in any culture's linguistic tradition, Christian or not, for its reach is truly universal. It may be that the major difference between Frei and Ricoeur is seen here, in the 'universal' Ricoeur finds uncovered in the New Testament. Ricoeur sometimes seems very close to the position of Northrop Frye, 
who holds that in the end we must see literature either as an 'endless labyrinth' or else as a 'total form'. Like Frye, Ricoeur opts for the Hegelian total form rather than the Derridian endless labyrinth. As the New Testament Gospels are, in addition to everything else, great literature, we should not be surprised if Ricoeur finds this same form embodied here. The unique referent of the Gospel narratives is not wholly cut off from other literary works. We come to understand its singular story by being familiar with the repertory, the archetypes, the 'order of paradigms' (Ricoeur) used in secular literature.

Almost as if he were responding to Hans Frei's affirmation of the selfreferentiality of biblical narrative, Ricoeur goes on to caution that we misunderstand the process of interpretation if we see it 'as some kind of interest in mastery or domination, in the fashion of rational reconstruction of a phenomenon or process' (see Ricoeur 1983: 10). He does not want us to think of the total form as a universal taxonomy of archetypes. His position is different from the classical structuralists on this point. And he carefully distinguishes his position from the more apologetic stances of Gaston Bachelard (who talks of universal 'elements of nature') and Mirce Eliade (who sometimes writes of 'cosmic dimensions', implying that all religious narratives refer to the same 'sacred'). But how does Ricoeur's view differ? The answer might be that, for Ricoeur, the secret order of the paradigms reaches its fullest expression in the Bible. To my knowledge, he has not explicitly said this in any of his published writings, but it seems to follow from his comments about Jesus, the 'Parable of God'. Biblical imagery, he has written, 'is dominated from above by apocalyptic imagery that, through forms difficult to number, turns on reconciliation in a unity (my emphasis) - the unity of a one yet triune God, the unity of humanity, the unity of the animal world in terms of the symbol of the lamb, of the vegetable world in terms of the symbol of the tree of life, and of the mineral world in terms of the heavenly city' (Ricoeur 1983: 10). This is the sort of narrative truth to which well-crafted fictional texts refer. It is safe to assume that Ricoeur finds this reconciliation in a unity expressed in the temporal world of the New Testament as well. And it may be in part his biblical emphasis that distinguishes Ricoeur from structuralists and comparative religionists like Bachelard and Eliade. Nonetheless, there is no mistaking that, whereas Frei with Barth concentrates on the particularity of Jesus, Ricoeur with Hegel emphasizes the universality of his Father's kingdom.

Here is a clear difference in the way pure and impure narrativists tend to read the synoptic stories. But we need not overemphasize it. It is true that for Ricoeur the secret order, the reconciliation in a unity, can be disclosed not just in the narratives of Jesus but in any culture's creative discourse. But this is not to say that every artist or reader of poetry is, on Ricoeur's view, some sort of anonymous 
Christian. It is one thing to express or encounter the mysterious power. It is another to come to affirm it. Trusting it as ultimately beneficent is something the Christian believer must choose to do. Making the biblical story one's own is a specific act entailing specific commitments. This is because the story names a particular agent as the focus of the unified God-and-world. Christians are those who experience in Jesus Christ reconciliation with their Maker. Christians are those who believe certain things, live a certain kind of life, align themselves with a specific community. To do this is to take a risk. For the dialectical narrativist, the scriptural stories do not insure faith; they are too extreme, to transgressive. And yet they do compete with other views: 'Religious language projects its radical vision of existence ... in tension and conflict ... with all the traits that carry this experience toward a shadowy humanism, or even an aggressive atheism' (Ricoeur 1975: 27-147 esp 128).

To my way of thinking, this is the way the ordinary Christian understands his story. In the crises of faith, we are carried toward a shadowy humanism and even atheism. But we know that it is silly to continue to use religious language if those interpretations are correct. The faith cannot ultimately be sustained if its critics are wholly right. So, while constantly learning from the humanist, Freudian, and Marxist reductions of Christianity, we must in the end always resist those interpretations. On Ricoeur's view, the atheist and the believer are in the same ballpark, playing the same game, speaking the same language. They genuinely disagree about something, and there is never any guarantee that, in the end, the atheist will be defeated. Nevertheless, the believer plays for this team against that one because he is totally committed to the One whose presence has been felt here.

Unlike Frei, Ricoeur allows both practically and theoretically that the New Testament's possible world is publicly intelligible. A correct grasp of it, however, will not come to the general public through reflection on a set of propositions. As Frei in his exegesis, so Ricoeur in his theory affirms the text's referent as inseparable both from its plot and from its reader response. For Ricoeur, this response is a concrete, pragmatic one; it is marked by faithfulness to God and solidarity with the poor and dispossessed. 15 It demands total commitment, for the biblical story overturns, dislocates, our anthropocentric 'project of making a whole of our lives - a project which St Paul identifies with the act of self-glorification' (Ricoeur 1975: 125). 16

Ricoeur's work provides a hermeneutical theory appropriate to a narrative interpretation of Scripture's reatistic stories. His literary principle of narrative meaning construes texts and readers as co-constitutive. Texts have meaning only to the extent that they have readers for whom they are meaningful. Readers, in turn, come to understand themselves only to the extent that they take the detour through 
the cultural texts of which they are a part. His philosophical theory of textual truth and reference holds that these stories do not refer to themselves. They refer to a possible world opened up between the text and reader. This world is inseparable from the text's depiction of agents and events; it arises only in the story's rendering of character and action. But it is also always possible for someone; it is in part the result of a reader's imaginative response.

When it comes to actual exegesis, the new theory does seem to encourage a slightly different way of reading the gospel. Ricoeur emphasizes the text's testimony to the parabolic nature of the kingdom of God, Frei the text's testimony to the parabolic nature of the kingdom of Jesus Christ. Of course, we have yet to hear what Ricoeur has to say about the cross, and we do not yet know what Frei might write about the kingdom. But the two would seem to agree that the referent of the text demands the reader's wholehearted consent, loyalty, trust, and concrete ethical commitment. For Ricoeur, the text not only has a meaning generally available to all, it also makes an intelligible, debatable truth claim. This claim, in part, is that we are not autonomous beings; we are fundamentally dependent upon each other and ultimately upon God 'the name of the unnameable' (see endnote 11).

The respective narrative theologies of Hans Frei and Paul Ricoeur represent exciting new developments in Christian thought. While there are unmistakable similarities between their views, they remain firmly opposed on the issue I have identified in my title. Frei thinks that the biblical stories are true, but he cannot see any point in trying to argue this matter publicly. Thus, to put it oversimply, he insists on meaning while sacrificing truth. Ricoeur not only thinks that the stories make truth claims, but he believes that they challenge the way modern philosophers think and talk about truth. In being willing to say what he means by 'true' here, he lends credence to the idea that the biblical narratives make genuine, public, perhaps even revolutionary claims about what is the case.

I have tried to show that Ricoeur's is the more appropriate hermeneutic theory for narrative theology. It identifies literary and philosophical principles that cohere with a narrative interpretation of the Gospels, and it understands religious stories in much the same way that many Christian speakers intend them. We should not forget that in an important way the work of the two men is complementary. Hans Frei shows us how to read the New Testament, Paul Ricoeur shows us how to talk about that activity. But their respective theological views - what I have called pure and impure narrativism - cannot so easily be harmonized. 


\section{ENDNOTES}

1 Neither Frei nor Ricoeur has published anything like a systematic 'narrative theology'. In Frei's case, we have a book (1975) that represents his actual interpretation of the New Testament story but only hints about his general interpretive principles. For these, see Frei 1974. In Ricoeur's case, we have several statements of his general hermeneutic theory: e g, Ricoeur 1976; 1974; 1977a. However, we have very little from him by the way of actual readings of biblical narratives. (Unfortunately he has not yet allowed his Sarum lectures to appear in print. 'Time and narrative in the Bible: Toward a narrative theology'.) In both cases, then, part of my task here is to extrapolate from the published works, imaginatively supplying a fuller account of each writer's 'narrativist' stance.

2 In order to avoid confusion, I must point out that Frei's first published book is a sustained attack on biblical critics who detach questions about the meaning of the biblical narrative from questions about its truth. Frei believes that this is a grave error; one cannot and must not separate the 'truth' of the story from its meaning. For Frei, then, the biblical story is the true account of reality; all theology should proceed from this basis. Having said this, my claim that Frei is not interested in questions about the story's truth will appear puzzling indeed. Have I completely misunderstood him? In think not. His is a radical and frank dismissal of all contemporary discussions of truth. Frei believes that the 'true' shape of reality is rendered in the cumulative biblical narrative, but he does not explain what he means by the word in quotes.

3 Pure narrativists grant realistic narrative a privileged position over philosophical, social scientific, historical, and poetic discourse. Impurists give narrative its own independence but construe it as dialecticaliy related to the others.

4 Such writers as William J Bausch (1984), Terrence W Tilley (1985), John S Dunne (1973) and Robert McAfee Brown (1980: 545-549) are pure narrativists. Other theologians who seem to share many of the family resemblances are Stephen Crites, George Lindbeck, Sallie McFague, George Stroup, Stanley Hauerwas, Michael Goldberg and James McClendon.

5 Such otherwise diverse writers as H Richard Niebuhr, Julian Hartt, William Beardslee, Philip Rossi, Basil Mitchell, Brain Wicker, William Christian, John Hick, Brian Hebblethwaite, and David Tracy exhibit many of the traits of impure narrativism.

6 In part, this is probably because Frei thinks the claim, like the story, is quite 
intelligible in its own right. Compare his comments on the 'pathos' of the late twentieth-century revival of talk about 'the historical Jesus'. That pathos lies 'in the increasingly difficult and specialized conceptual apparatus that has to be invoked in this and cognate schemes in order to rescue the meaningfulness, the intelligibility of a supposedly universal claim ... said to be of utmost importance for all sorts and conditions of men' (Frei 1974: 229).

7 Frei (1975: xvi n 1) wants us to understand hermeneutics in 'the oldfashioned, rather narrow, and low-keyed manner as the rules and principles for determining the sense of written texts'. Until a general hermeneutic theory appears that can treat these large-scale issues without compromising the uniqueness of the gospels, we must remain content with the more modest view of hermeneutics' (Frei 1975: xvii). I want to argue that Ricoeur's 'high-powered' hermeneutic is not only more fitting than Frei's 'modest' one, but that it is also not 'tyrannical' in the way that the 'new hermeneutics' may have been.

8 Postmodern philosophy abounds with antifoundationalists. I believe that 'postmodern' theologians should think carefully before casting their lot here. Almost every view has some underlying principle or theory. And, no matter how we might try to ignore, underplay, tease, or deride it, it always seems to carry a weighty theological agenda. Frei (potentially an antifoundationalist himself) is a case in point. Is it not better that we recognize the foundations and either affirm or change them - than pretend they are not there?

9 It is worth remarking that Frei (1975: xv, 104) seems to think of the gospel stories as having a singular, unified, and transparent meaning. They are not indeterminate, opaque, or multiple (as Frank Kermode (1979) has recently argued with regard to Mark). I do not mean to imply that Frei thinks the gospel's meaning simple. His interpretation in Identity actually implies a very complex church dogmatics. However, the meaning of the gospel does have an undeniable quality of unicity for him; the meaning of the Jesus story is found in the identity description and contemporary presence of the singular man Jesus of Nazareth. It is not likely that Frei's repeated uses of the definite article and the singular noun are unintentional.

10 The view is represented most clearly in theology by DZ Phillips (1965) and Paul Holmer (1975). These writers are surely purists when it comes to narrative. Holmer (1978: 69) says: 'The logic of the discourse of science is not the same as the logic of religion .... Their kinds of explanation are in fact incommensurable ... hence there is not logical incompatibility of a radical sort'.

11 Ricoeur (1977: 26) explains the relationship of these hermeneutic fields like this: 'The biblical hermeneutic is in turn one regional hermeneutic within a 
general hermeneutic and a unique hermeneutic that is joined to the philosophical hermeneutic as its organon. It is one particular case insofar as the Bible is one of the great poems of existence. It is a unique case because all its partial forms of discourse are referred to that Name which is the point of intersection and the vanishing point of all our discourse about God, the name of the unnameable'.

12 Ricoeur's (1984) understanding of plot - or 'emplotment' - is roughly equivalent to Frei's understanding of narrative 'depiction': the interaction of character and happening directed toward some telos. However, we should note that, unlike Frei, Ricoeur has on occasion affirmed the notion of a 'deep structure' of a text. In the light of Frei's criticisms, this calls for a brief comment. Structuralists such as Propp, Lévi-Strauss, and Bremond understand narrative texts as temporal 'surface' manifestations of a deeper ahistorical figure. For many of these thinkers, deep structure means a logical, atemporal matrix of operations, sometimes represented as a box of paired oppositions (e g, 'raw versus cooked', or 'order versus chaos'). This is not Ricoeur's view: he refuses to think of narrative as a one-way street from the 'real' deep structure to the 'apparent' narrative surface. While he concedes that we can learn a great deal from structuralist methods, he does not go along with structuralism's basic presupposition. Compare his criticism of Ivan Almeida's belief that 'every narrative maneuver can be represented on a semiotic square'. Ricoeur (1981b: $72 \mathrm{n} 5$ ) says that this method loses the essence of the narrative, what he calls its temporal advance, or its course.

13 Ricoeur, of course, has not been alone in arguing such a view. Kenneth Burke's (1962: xvii) dramatistic notion of literature implies that all human expressions, from 'systematically elaborated metaphysical structures' to 'legal judgments', 'poetry and fiction', and 'political and scientific works' can be understood either as dramatic stories themselves or as fragments of some larger story.

14 On Ricoeur's (1977b:21) view, the claims of artistic and religious discourse challenge the presuppositions of ordinary discourse. Truth claims of ordinary discourse are based on two assumptions: that truth is objective and can be measured by the criterion of empirical falsification, and that truth appears to an autonomous thinking subject, a consciousness completely in control of itself. Ricoeur says that religious truth ('revelation') 'violates' these two assumptions. Truth, according to religious texts, is not transparent (it cannot be assessed simply by using the methods of adequation or falsification). Nor, according to the biblical stories, are human beings sovereign, selfpossessed individuals who can objectively survey such claims. Thus, Ricoeur's theory of truth competes 
with the major alternatives of analytic philosophy.

15 Ricoeur's narrativism has great affinity for the themes of liberation theology as sounded, e $g$ in Metz (1980). Compare Frei's (1975: 156-157) cautions about reducing religious faith to political commitment.

16 Ricoeur's ethics is not, however, an ethics of unlimited deferral and displacement. For such a deconstructive view, see Crossan (1980). For his part, Ricoeur (1975: 126) says that he does not want to be accused of 'reducing the Christian reading of existence to a single aspect, that which Kierkegaard brought to its highest point of virulence, namely, paradox, and thus of neglecting its other aspects'. 
Works cited

AUERBACH, E 1953. Mimesis: The representation of reality in Western literature.

Princeton: Princeton University Press.

BAUSCH, WJ 1984. Storytelling: Imagination and faith. Mystic, Conn: 23rd Publications.

BROWN, RM 1980. Starting over: New beginning points for theology. Christian Century 97, 545-549.

BURKE, K 1962. A grammar of motives. Cleveland: World Publishing Co.

CROSSAN, JD 1980. Cliffs of fall: Paradox and polyvalence in the parables of Jesus.

New York: Seabury.

DUNNE, JS 1973. Time and myth. New York: Doubleday \& Co.

FREI, H 1974. The eclipse of biblical narrative: $A$ study in eighteenth and nineteenth century hermeneutics. New Haven: Yale University Press.

FREI, H 1975. The identity of Jesus Christ: The hermeneutical bases of dogmatic theology. Philadelphia: Fortress.

FREI, H 1982. Theology and the interpretation of narrative: Some hermeneutical considerations. Lecture presented to the Narrative Interpretation and Theology Group of the American Academy of Religion.

HOLMER, P 1978. The grammar of faith. New York: Harper \& Row.

KERMODE, F 1979. The genesis of secrecy: On the interpretation of narrative.Cambridge, Mass: Harvard University Press.

MacINTYRE, A 1981. After virtue. Notre Dame: University of Notre Dame Press.

METZ, JB 1980. Faith in history and society. New York: Crossroad Publishing Co.

PHILLIPS, DZ 1965. The concept of prayer. London: Routledge \& Kegan Paul.

RICOEUR, P 1974. The conflict of interpretations: Essays in Hermeneutics.

Evanston, 111: Northwestern University Press.

RICOEUR, P 1975. Biblical hermeneutics. Semeia 4, 27-147.

RICOEUR, P 1976. Interpretation theory: Discourse and the surplus of meaning. Fort Worth: Texas Christian University Press.

RICOEUR, P 1977a. The nule of metaphor: Multi-disciplinary studies of the creation of meaning in language. Toronto: University of Toronto Press.

RICOEUR, P 1977b. Toward a hermeneutic of the idea of revelation. $H T h R 70$.

RICOEUR, P 1978. Manifestation and proclamation. Journal of the Blaisdell Institute 12.

RICOEUR, P 1980. Review of Jauss, H-R 1977. Ästhetische Erfahrung und literarische Hermeneutik. Munich: Fink. Révue de metaphysique et de morale 85.

RICOEUR, P 1981a. The biblical worldview and philosophy. National Institute for Campus Ministries Journal 6. 
RICOEUR, P 1981b. The Bible and the imagination, in Betz HD (ed), The Bible as a document of the university. Chico: Scholars Press.

RICOEUR, P 1983. 'Anatomy of criticism' or the order of paradigms, in Cook E (ed) et al, Centre and labyrinth: Essays in honor of Northrop Frye. Toronto: University of Toronto Press.

RICOEUR, P 1984. Time and narrative. Chicago: University of Chicago Press.

TILLEY, TW 1985. Story theology. Wilmington: Michael Glazier.

WITTGENSTEIN, L 1966. Lectures and conversations on aesthetics, in Psychology and religious belief. Edited by $\mathrm{C}$ Barrett. Berkeley: University of California Press.

WITTGENSTEIN, L 1969. Philosophical investigations. 3rd ed. New York: Macmillan Publishing Co.

YU, A 1978. Recovering the sense of the story. JR 58, 198-203. 